Neighborliness and Decency, Witchcraft and Famine: Reflections on Community from Irish Folklore

Author(s): Ray Cashman

Source: The Journal of American Folklore, Winter 2021, Vol. 134, No. 531 (Winter 2021), pp. 79-100

Published by: University of Illinois Press on behalf of American Folklore Society

Stable URL: https://www.jstor.org/stable/10.5406/jamerfolk.134.531.0079

\title{
REFERENCES
}

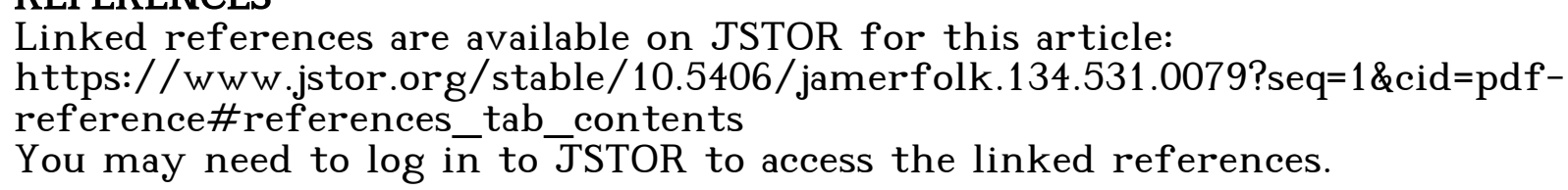

JSTOR is a not-for-profit service that helps scholars, researchers, and students discover, use, and build upon a wide range of content in a trusted digital archive. We use information technology and tools to increase productivity and facilitate new forms of scholarship. For more information about JSTOR, please contact support@jstor.org.

Your use of the JSTOR archive indicates your acceptance of the Terms \& Conditions of Use, available at https://about.jstor.org/terms 
Ray CASHMAN

\section{Neighborliness and Decency, Witchcraft and Famine: Reflections on Community from Irish Folklore}

Many examples of Irish folklore reflect and instill enduring conceptions about the workings, vulnerability, and viability of community, which is understood to be a doing, a project in need of continual maintenance. Arguably, there has been no more devastating blow to the vernacular understanding of community as social contract for mutual support than the mid-nineteenth-century Famine in Ireland. If folklore provides models for contemplating and reproducing ideas about how community may be enacted, it also bears witness to the haunting consequences of abandoning community.

Keywords

AFs ethnographic thesaurus: Community, evil eye, fairies, famines, neighborliness, space and place, reciprocity, collective memory, witchcraft, worldview

LET US BEGIN WITH A PROPOSITION-not a new one-that much of what we have termed "folklore" serves as a kind of vernacular social theory, a means through which people represent themselves to themselves and think through what it means to be an individual within a group, typically in the midst of change or challenge (cf. Cashman 2008b, 2016; DaMatta 1992; Jackson 2013; Noyes 2003a, esp. Part II). Many examples would serve, but consider Irish fairy legends for a brief illustration.

In an elaborate web of inherited stories, the fairies-na daoine uaisle, the gentle folk or the good people-occasionally intrude into our world to reward good behavior or punish un-neighborly transgression - removing a hunchback's hump in appreciation of his reverence, crippling another man who cut down a fairy thorn tree. The fairies also steal back to their Otherworld our wise midwives, talented musicians, and young children full of promise-those people we value or aspire to become. Altogether, the fairies constitute an alternative society parallel to our own, and their Otherworld offers a removed but relevant realm through which to explore difference and desire, fate and fortune, the normal and the abnormal-among other potentially disturbing

RAY CASHMAN is Director of the Folklore Institute and Professor in the Department of Folklore and Ethnomusicology at Indiana University 
issues that are often difficult to articulate directly. As Angela Bourke observes, the otherness of fairies invites us to explore "the liminal, the marginal, and the ambiguous, whether in time, in the landscape, or in social relations," and this makes the fairies important cognitive tools for contemplating the nature of self and society (1999:13).

In narrative, humans treating fairies with reverence and reciprocity (or else) imparts applicable patterns for negotiating relationships between all manner of us and them in everyday life-human/non-human, male/female, old/young, and so on. To consider someone "away with the fairies" explains eccentric, even aberrant behavior, helping to integrate otherwise idiosyncratic individuals into a heterogenous conceptual whole. A formulation such as "away with the fairies," whether apt metaphor or fast belief, keeps the door open to difference within certain fungible limits without undermining-and in fact setting in relief-shared norms and social expectations.

Telling, listening to, and internalizing fairy legends-no less than avoiding or acting deferentially at places associated with fairies-are prime examples of the kind of everyday practices that inform what Pierre Bourdieu calls habitus - the orientations, values, and durable, transposable dispositions that individuals acquire through shared practices that evolve in response to shared conditions over time in a given social environment (1977:72-94). The part of habitus (and more broadly, worldview) that speaks to the nature of self and society-the possible and proper relationships between the individual and collective-is comprised of such things as Western Apache place names that recall narratives delineating the moral teachings of shared history (Basso 1996); Mexican corridos that interrogate the legitimacy of violence in the conduct of social life (McDowell 2008); US rumors and legends about welfare fraud that shape both debate and policy concerning poverty, fairness, and our obligations to each other (Mould 2020); Newfoundland spells and counterspells that underscore the power and fragility of social interdependence (Rieti 2008); and Catalan festivals that seek to both acknowledge and ameliorate social divisions in the midst of significant obstacles to collective solidarity (Noyes 2003a). Put another way, many examples of folklore from Irish fairy legends to Catalan festivals serve as a vernacular way of theorizing, among other things, the nature of community-its workings, its vulnerability, its viability.

This, of course, begs the question, What is community? In one sense, there is no such thing as community. Community is an idea, and like all ideas, it is culturally relative and does not exist except through a cycle of enactment, representation, further enactment, and so on. ${ }^{1}$ Folklorists have done a thorough job contemplating the social base of folklore (Bauman 1972a; Bauman and Abrahams 1981; Noyes 2012), theorizing the mutual constitution of social networks and social imaginaries (Noyes $2003 \mathrm{~b}$ ), and wrestling with the imprecision of the term "community" while recognizing its staying power (Noyes 2016:364n19). Although there are always compelling analogues between "high" and "low" theorizing to highlight and explore, here, I am interested less in academic models of community and more in vernacular theorizing about community evident in folklore found in a given time and place. ${ }^{2}$ There is an ethnographic motivation to this focus on the vernacular and the particular. How community is enacted, remembered, and otherwise made manifest in the texts, practices, and beliefs of a given group of people offers us a window into their community logics, a window into aspects of their habitus and worldview. 
If we are interested in a long-established conception of community in rural Irish contexts, as I am here, we find plenty of evidence in Henry Glassie's ethnographic exploration of folklore and daily life in Ballymenone, Co. Fermanagh, of the 1970s and 1980s. Focusing on everyday acts of reciprocal hospitality, entertainment, and labor sharing, Glassie derives an insider's understanding of community defined not by space-as in everyone within a given townland or parish constitutes a community-but by participation. That is, in Ballymenone, community is defined by social networks of willing participants bound not by affection - and certainly not by shared politics-but rather by a social contract for mutual support, one sanctified in the Christian injunction to love one's neighbor as oneself (Glassie 1982:22-30).

Lest you think this conception of community to be romantic or superorganic, note that, of course, individuals have agency, and they are quite capable of opting out of community thus conceived, as we will see. But this generally held understanding of community as an ideal is clear in ethnographic accounts of rural life in Ireland, from Conrad Arensberg's work in Co. Clare of the 1930s through Glassie's work in Co. Fermanagh of the 1970s and 1980s, and, if I may, my own work in Cos. Tyrone, Donegal, and Cork from the 1990s to the present. Such an understanding of community resonates in additional places and times in Ireland, as the manifold holdings of the National Folklore Collection [NFC] at University College Dublin attest. ${ }^{3}$

If I am adding anything new here, it is a slight shift in focus to emphasize examples of Irish folklore that pinpoint threats to community and suggest how such threats can be diminished or overcome. Furthermore, in extreme cases when such threats are insurmountable-when community disintegrates beyond repair-we can appreciate how some forms of folklore cast the idea of community into relief through its haunting absence. Disparate though my examples will be, they reveal a long-standing commitment to unstinting generosity and generalized reciprocity that comports with Marcel Mauss' observations about the mutual obligations established by gift giving ([1950] 1990). Likewise, the flip side of the commitment to reciprocity seems to be a deepseated ambivalence toward money, profit, and ambition in "a world of limited good."

With the phrase "in a world of limited good," I am invoking George Foster's observation that in the vernacular social theory of many societies, one encounters the shared postulate that there is a finite amount of good in the world, so that one person's gain entails another's loss (1965). Such a perspective reinforces a conception of community as a social contract for mutual aid, a charter for continual reciprocation and co-operative co-existence. The prospect of community, then, is threatened by any breach of that social contract, including the efforts of any person to advance his or her own interests, which is understood to come inherently at the expense of others. Let us begin anecdotally, starting in the near present and working more or less backward in time, to see where a string of vignettes and associations takes us.

\section{Community Threatened and Maintained}

In 1999, I walked into Michael Gallen's small electronics shop in Castlederg, Co. Tyrone, and bought a dual cassette tape recorder in order to make copies of field recordings for people who had helped me during my early fieldwork in Ireland. 
(Believe it or not, the analog world was not that long ago.) Michael knew me because we had been neighbors for several months, and honestly that is why I went to his shop even though I might have found a better price in a bigger town such as Omagh or Strabane. I paid Michael's advertised price in cash, and he handed me back the correct amount of change from the till. Then, as I thanked him and turned to leave, Michael said, "Hang on a wee minute," reached into his pocket, and handed me a one-pound coin.

\author{
"What's this?" I asked. \\ "A luck's penny," he said. \\ "What's a luck's penny?" I asked. \\ "Just a custom we have here," he said, without further comment.
}

Later, my friend and next-door neighbor Danny Gallen clued me in. He recalled that at fairs in the recent past, the buyer and seller of livestock would haggle to determine a mutually agreeable price, and then the seller would be expected to give back some small amount of the profit depending on the value of the animal sold. A luck's penny could be offered in other situations as well-anytime there is a monetary exchange for goods and services. I quote Danny from a recorded conversation on January 17, 1999:

\footnotetext{
They talk about luck, keeping the luck flowing. But you know, it's also a way of keeping that connection going, see. You're not going to go back to that man if you think he's taking advantage, but you might if he's decent with you. The luck's penny back is a way of saying that, that the two men have a kind of partnership and may do business again.
}

In a sense, this custom deflects attention from the purely financial aspects of the transaction. The luck's penny, a performance of "decency," also points to a kind of anxiety over the negative reciprocity inherent in capitalism, a system in which sellers not only compete with the market but also with buyers, trying to maximize profit at their expense.

In the terms used by Marshall Sahlins for societies without market economics (1972), later refined by David Graeber for market-based societies (2001), my transaction with Michael Gallen started out as something like balanced reciprocity: two things of roughly equal value were exchanged, the exchange was immediate, and it did not entail future obligations or establish social relationships. The transaction ended, however, with a dash of generalized reciprocity in the form of the luck's penny. Generalized reciprocity involves a gift being offered without the expectation of an immediate return but with a vague expectation of reciprocation in the indefinite future. This constitutes a bid to establish or maintain a relationship, focusing on the social aspects of the exchange over and above individual material interests.

More interesting, perhaps, after explaining the luck's penny, Danny continued with a discussion of other local economic habits and customs. For example, Danny mentioned that he has a tab at certain shops in his rural parish of Aghyaran and in the nearby town of Castlederg. Even though he might be in a position to pay off all his debts, it would be taken as an unmannerly, unfriendly, and un-neighborly gesture 
to do so. That stumped me. I wondered out loud about how a shopkeeper could be offended by being paid what is owed. Danny replied:

Because it's not just about the money. Well, it is, if we're talking a lot of money-you can't be in big, big debt-but having a little debt is expected, like. You know, it's about the partnership. If I paid off my debts to Danny McHugh [a local shopkeeper], now, he'd think we were through, or that I'd be going somewhere else to buy meal and the odd loaf of bread. (personal communication, January 17, 1999)

To my surprise, the symbolic significance of debt and credit in the social networks of farmers and shopkeepers that Danny described was almost exactly what Conrad Arensberg described when I went back to re-read his 1937 ethnography The Irish Countryman. To Danny Gallen's surprise, a few years later, shopkeeper Danny McHugh stopped by and handed him a final bill. The two Dannys had had a falling out, so when Danny McHugh called in Danny Gallen's debts, it effectively ended their relationship. (Years later they came to a reconciliation.)

With those examples in mind, community starts to look like a web of mappable, interconnecting, mutually beneficial transactional partnerships and networks that are continually maintained, renegotiated, or, in some cases, terminated. I was prepared for this vision of community by labor and equipment swapping arrangements, known by various terms such as "cooring," "swapping," "joining," or "neighboring" (Bell 1978; Glassie 2006:25-6, 444). Likewise, the same understanding of community is enacted-after work is done-through traditions such as mumming (Cashman 2007; Glassie 1975) and through the assembly of all near and far neighbors at wakes regardless of sectarian and other social divides (Cashman 2006, 2008a, 2008b). But before the luck's penny conversation, I had not considered the unstated yet apparently widely understood mutual obligations established through debt and credit.

In some ways, money changes everything (McCabe 2018; cf. Lauper 1983). We have already seen more than a hint of apprehension about this slippery, compoundable, potentially exploitative market phenomenon, money. Michael Gallen's luck's penny was a gesture at redefining the event that brought us together in social rather than merely financial terms. But in other ways, money changes none of the underlying community logics that maintain neighborly equilibrium through carefully orchestrated reciprocity; rather, it provokes counteraction. In the case of the luck's penny, handling money affords a kind of dramatization of community in an attempt to temporarily resolve some of the ambivalence that money invites.

Consider another piece of the community puzzle. Danny McHugh's shop reminds me of a recurring character type in anecdotes told about local characters in Aghyaran, Co. Tyrone, and elsewhere. The character type in question is a relatively new one: the modern, competitive farmer-capitalist who sacrifices neighborliness in his feverish pursuit of wealth (Cashman 2008b:172-82). In one popular anecdote, a local big farmer who fits this type is said to have rushed into Danny McHugh's shop around dinnertime. Needing to feed his hired workers, the farmer grabs up four loaves of bread, throws down his money on the counter, and makes for the door without any of the customary polite chat and sociability_often a main reason for stopping and lingering at the shop in the first place (cf. Bauman 1972b). Danny McHugh points 
out that one of the loaves the farmer grabbed up is not sliced. The man throws down the loaf in disgust, saying, "Och, Chrissakes, I haven't time to be slicing bread!" and storms off. There is in fact a considerable cycle of similar anecdotes about this man and others like him, told at wakes and ceilis (nighttime social visits). As a whole, these anecdotes make fun of this capitalist drone type for extreme tightfistedness, haste, and abandoning traditional norms for sociability. No chance of a meitheal-a volunteer group for co-operative labor-being made up of this sort of character. The farmer-capitalist has opted out of community as traditionally understood.

Consider another vignette. On June 18, 2014, I walked to the house of my friend Packy Jim McGrath, who lived at the time on an isolated farm in the Lettercran area near Pettigo, Co. Donegal. On the way, I saw a notice on a gate declaring that tests were being conducted to determine the feasibility of erecting electricity-generating windmills in the area. When I asked Packy Jim about the notice, his main concern was the inevitable conflicts that arise when a wind farm company offers one landowner a lucrative leasing arrangement and less or nothing to the neighboring landowners. Moreover, it takes relatively little for people on adjoining land to object and wreck a neighbor's deal with these companies. Acting as vernacular social critic, Packy Jim assessed the situation as follows:

Old jealousy, because somebody's getting a couple of quid out of it. Oh now, I'm telling you, old jealousy, that's the Irish for you! It's running away from father to son, to grandfather to great grandfather, all the way back for a thousand years, I would think, running through the bloodstream or the genetics or whatever the hell you like to call it. That's what I would think. (personal communication, June 18, 2014)

As our conversation unfolded, Packy Jim made a connection to the evil eye, also known as "blinking," which he describes as a jealous look that can drain the luck or prosperity from other people or their possessions. He illustrated this with a story concerning a local man known as Black Henry McCutcheon, who was accused of having the evil eye. An oddball, a mama's boy, and a Protestant in a largely Catholic district, McCutcheon was falsely accused, according to Packy Jim. But after rumors compounded and one of his neighbors fabricated the deaths of two young calves - said to have wasted away from the evil eye-McCutcheon was stigmatized and shunned. ${ }^{4}$

With treachery and neighborly discord a clearly established theme, Packy Jim launched into what turned out to be a localized version of a widespread legend that is known throughout Ireland, Britain, Scandinavia, Germany, and parts of North America. His story featured a named local man said to be a "witch," who-as witches do-transforms into a hare to steal milk by suckling a neighbor's cow. In doing so, the witch magically hopes to acquire that cow's dairy output and particularly the butterfat content necessary for churning butter, traditionally a reliable source of income. Upon discovering the witch in the form of a hare in his byre, however, the cow's owner shoots the hare, and later the witch's identity is revealed when he transforms back into human form with a tell-tale wound. ${ }^{5}$

Not long afterward, Packy Jim followed his witch hare story with a childhood memory of a local woman named Mrs. Turner who had a widespread reputation for hospitality. Packy Jim and his mother used to pay Mrs. Turner a small sum to breed 
their turkey hens with her male turkey, and Mrs. Turner, in turn, would offer them a small gift-such as tea, sugar, or tobacco over and above the exchange itself-a kind of luck's penny. During one visit, Packy Jim remembers Mrs. Turner talking about a neighbor woman, Alice Monaghan, whom she suspected of envy and witchcraft. According to Mrs. Turner, one day she spotted a suspicious hare in her farmyard that bared its teeth at her. In response she belted out a chant-like anti-charm-"hares and witches and dirty butter!" said three times-until the hare jumped up and hopped away. Apparently, she had no more trouble from the neighbor woman after that. ${ }^{6}$

Note that I am treating in the same category Packy Jim's two witch hare stories and his evil eye story-and to some extent even the contemporary gossip and wrangling about wind farms-because they all speak to the same constellation of concerns. A common factor here is the anxiety arising from a conflict of economic interests and especially from the difficult balance to be struck between personal gain and community well-being.

Drawing from a similar corpus of stories concerning witchcraft and supernatural aggression in Ballymenone, Co. Fermanagh, Henry Glassie adduces a set of principles concerning prosperity and profit (1982:527-51). The basic local understanding is that making a living requires intelligence and hard work, but this is not enough to make one rich. There are two paths to wealth, both of which require something more. One path involves evil, specifically witchcraft, which may be characterized as the use of magic to circumvent hard work and intelligence, gaining an easy profit at the expense of your neighbors. The other path requires luck and the continued application of intelligence and hard work during the good times, which are not necessarily deserved or earned, but are bestowed by God nonetheless. If the first path springs from greed, envy, spite, and the willingness to opt out of community, the second path comes with the obligation of generosity to one's neighbors so as not to cross or join paths with the witch. So, to be a witch is to steal and to advance one's interests at the expense of others, opting out of community and disrupting community equilibrium. To be a member of community is to share the profits of and extend the circulation of luck.

Note that Mrs. Turner is the opposite of her witch nemesis, Alice Monaghan, in giving Packy Jim's mother a great quantity of tea in a time of scarcity. Mrs. Turner is open-handed beyond the obligations of their financial transaction. Consider, too, that anxiety over profit may revolve logically around the dairy (cf. Glassie 1982:549). Milk is the product of God-given natural resources, and the butter churned from it is sold for a profit to outside parties - not unlike the wind-powered electricity sold to urban suppliers. With butter, the ideal counterbalance to the destabilization of profit is to share this gift within the community in symbolically crucial acts of hospitality and reciprocity during social visits, blunting the excessive gain of a purely self-serving, profit-driven enterprise. As yet there is no equivalent line of reasoning, ritual, or custom to settle the current wind farm wars. But whether one reaps profit from wind, or from rain, grass, and cows, profit in itself is not considered wrong; the problem is profit that is ill-gotten and selfishly used. It is "dirty butter" from which nothing good can come, and it connects conceptually to many other forms of ill-fated profiteering.

Let us briefly cast farther in space and backward in time to late nineteenth-century Ballyvadlea, Co. Tipperary. In her engrossing book The Burning of Bridget Cleary, Angela Bourke notes that the striving, upwardly mobile ways of a childless young wife 
and financially successful seamstress, Bridget Cleary, were perceived by her husband, family, and neighbors as privileging short-term personal gain over long-term familial and communal stability (1999). Furthermore, her purportedly uppity ways were taken as evidence of her association with the fairies and supernatural profiteering, and this interpretation gave shape to the rapidly escalating conflict between Bridget Cleary and those closest to her. Indeed, the fairy association fueled the abuse that ended in her death when she was burned as a changeling, thought to be left in place of the real Bridget Cleary.

This was 1895 . In other words, this was a recognizably modern world of electric illumination, widespread literacy, and timely trains connecting home to market and beyond; a world entirely mapped by the Ordnance Survey at a scale of 6 inches per mile that registered every house, byre, bog, and fairy fort; a world of codified laws and colonial governance enforced by a widely garrisoned police force and military.

The murder of Bridget Cleary implicates several critical, interconnected issuestradition, modernity, power, gender, conformity, deviance, belief, worldview-and it points to crises in community and family logics in the wake of colonialism and capitalism. No doubt, the perception of Bridget Cleary's behavior as provocative was compounded by patriarchal gender politics. In a time and a place of changing gender dynamics - in the wake of the emasculation of colonial domination-Bridget Cleary's individualism, success, and growing autonomy were interpreted by the men (and women) in her life as particularly transgressive. If fairy lore leaves a conceptual door open to difference and heterogeneity within certain fungible limits, as claimed earlier, perhaps this was an extreme case when formerly fungible limits were suddenly no longer fungible. For all its extremity and tragedy in terms of gender politics, this case study also bears witness at base to underlying apprehensions in the face of abruptly established modernity-anxieties over individualism versus collectivism, doubts about legitimate versus illegitimate ways of creating profit, and concerns that everyone contribute in the social contract for mutual support that is community.

Such angst in the wake of new capitalist logics and threats to old collectivist ideals seems to have been around for some time and seems to have had a lasting resonance. More broadly, the evidence from Castlederg, Aghyaran, Lettercran, Ballymenone, and Ballyvadlea points us back to that long-standing postulate that this is a world of limited good, decidedly different from the American dream of unlimited opportunity. In such a system, a luck's penny makes sense. A small symbolic return of profit keeps it in circulation, blunts the unlucky negative reciprocity inherent in capitalism, and helps maintain interconnected webs of co-operation. Ambition and profit are both provocative and potentially threatening to the viability of community in a world of limited good. The examples of Irish folklore discussed here, and many more besides, bear witness to people through time and across space being well aware of and actively resisting such threats to community through thought, word, and deed.

\section{The Ghosts of Community Abandoned}

The preceding examples gradually worked backward in time to suggest enduring ideas in the vernacular understanding of the nature and workings of community. If the Bridget Cleary case represents an ideology of community, distorted by additional 
anxieties and agendas, being taken to one extreme-the annihilation of an individual-consider the opposite extreme where the ideology of community degrades to such an extent that we all fail each other entirely. Presumably every group of people in every age witnesses threats to the prospect of community. In the Irish context, this prospect was never more threatened than during the Irish Potato Famine or Great Hunger (1845-1852). ${ }^{7}$ Shocking, traumatic, and almost (but not quite) untellable, the Famine was nothing if not a devastating blow to the vernacular concept of community delineated here. ${ }^{8}$

There is a wealth of literature concerning the Famine, its effects and affects-both personal and collective, local and global-and much is open for debate. But certain generally accepted aspects of this period bear repeating. The Famine was the result of a natural disaster, a fungal blight accidentally imported from North America that destroyed Ireland's potato crop for several consecutive years. But this natural disaster was catastrophically exacerbated by human factors, in particular an inadequate, seemingly indifferent government response and a long, complicated history of colonialism that left the poorest segment of Irish society entirely dependent on potato cultivation and most vulnerable to starvation and disease when the crop repeatedly failed.

In statistical terms, using conservative estimates, the Famine killed 1 million people and forced another million to emigrate. The population of Ireland declined from roughly 8 million to 6 million, which is to say that, on average, island-wide, one in four people were simply gone in less than a decade. This is to say nothing of more desperate demographic shifts in the hardest-hit areas where entire families were wiped out and villages abandoned.

In terms relevant to the community logics discussed here, neighbors were pitted against neighbors as the lower classes were forced to compete over dwindling food supplies and eventually to avoid each other altogether as infectious disease spread. To make matters worse, a striving merchant class-derisively referred to as "gombeen men"-profited from rising prices and exploitative money-lending practices. The government strictly adhered to laissez-faire economics, treated the Famine as a market correction, and provided virtually no humane or effective aid. In the aftermath, large farmers consolidated capital in the form of cheap, newly available land, compounding their profits for generations to come.

As Breandán Mac Suibhne observes in The End of Outrage, market-driven inequality and individualism had already been on the rise by the eve of the Famine (2017a). But the severity and ubiquity of the Famine occasioned unprecedented callousness and-paraphrasing the words of antiquarian and witness to the Famine John O'Donovan-these dark years ushered in an "era of infidelity" to much of what the dead held dear (Mac Suibhne 2017a:4). Mac Suibhne is delicate but astute in raising the uncomfortable truths that not all survivors were victims (nor were they all villains) and that what may be most characteristic of the Famine is that "gray zone" of human raggedness and failure to live by long established imperatives of reciprocity and neighborliness. Accounts of unburied bodies and mass graves, pitiful suffering and heartless depredation, abandonment, murder, and even cannibalism are welldocumented; in the aftermath of the Famine, remembering widespread inhumanity and recalling one's direct or indirect complicity in the complete breakdown of community evoked shame for many, silence for others (Mac Suibhne 2017b). ${ }^{9}$ 
So how can we even approach the Famine, its representation and conceptualization, whether through folklore, literature, historiography, or some other means or medium? The short answer is "indirectly". The folkloric record-which should offer the unofficial grassroots perspective-is not so much silent as enigmatic, requiring special hermeneutic efforts to "hear." In large part, the range of legendary materials representing the Famine are fragmentary, coded, indirect, and often opaque, as observed by the work of Cormac Ó Grada (1994, 2001), Cathal Póirtéir (1995a, 1995b, 1996), and Niall Ó Ciosáin $(1995,2001,2004)$. But if folklore provides models for contemplating and reproducing ideas about the nature of community, it stands to reason that folklore could bear witness also-however indirectly—to the haunting consequences of abandoning community.

A prime example that bears such witness is known as the hungry grass or an féar gorta. For centuries, there have been recorded accounts of people traveling over particular spots in the Irish landscape and being overcome by sudden weakness and, most of all, an insatiable hunger. The hunger and lethargy associated is said to be severe enough to kill victims, but they can be cured by eating even a small bite of food or, failing that, chewing on something such as shoe leather and swallowing the juices. Even smoking tobacco is said to break what may be experienced as something like a deadly spell that can nonetheless be broken. The hungry grass or an féar gorta names both the ordeal and the culprit.

Such an extraordinary somatic experience, linked to particular locations, makes for remarkable narratives that circulate still. Indeed, in June of 2018, I recorded secondhand accounts of experiencing the hungry grass from Donie O'Sullivan of Lombardstown, Co. Cork, and John Joe Kavanagh of Dromahane, Co. Cork. Examples drawn from contemporary fieldwork, twentieth-century archival materials, and nineteenth- and twentieth-century journalism and popular literature include legends, personal experiences, discussions of precautions and cures, and belief statements. ${ }^{10}$ Roughly two-thirds of these materials identify an origin for the hungry grass, one usually taken to be supernatural and often associated with the Famine, about which more below.

Consider a typical example of a brief secondhand account recorded in Bruncrana, Co. Donegal, from an elderly man interviewed for the Irish Folklore Commission's 1937-1939 Schools' Collection project: ${ }^{11}$

\footnotetext{
People used to get "féar gorta" or get weak coming home from markets and fairs. This grass, if you walk on it, you will not be able to go any further without eating something. There is "féar gorta" at Mamore, at Slavery, and at many other places. There is hungry grass about a mile from Clonmany next [to] this parish. If anyone walks over it they get weak. My Grandfather, William McLaughlin, Carva, said that one day he and a young man were coming from Clonmany and the man got weak at this spot and my grandfather had a few [oat] cakes in his pocket and he gave them to the man to eat and he got alright again. Any person going to Clonmany always took a piece of oat bread with them for fear the hunger might overcome them at this spot. (NFC S 1112:390) $)^{12}$
}

Even in such a short text, we have all the basic elements of severe hunger and weakness experienced at a certain place. More than a setting, this place triggers the phenomenon, which can be cured only by ingesting something, however minimal. In addition, there is mention of the custom that people in the past, being aware of the risk of the 
hungry grass, regularly carried food with them on journeys, usually small cakes or biscuits of oat bread, a motif that re-emerges time and again in hungry grass lore.

Note that the informant here, William McLaughlin - the same name as his grandfather-was 86 years old when his account was recorded in 1938. Therefore, he was born at the very end of the Famine, and as you might expect, there are connections between the hungry grass and the Famine to explore. But the fact is that reports of the hungry grass pre-exist the mid-nineteenth-century Famine. The event William McLaughlin describes-if it happened in his grandfather's youth-would have taken place before the Famine. Indeed, there are conceptual parallels to the hungry grass in William Camden's Britain (1610) and arguably in the Ulster Cycle, which is set in the Iron Age but was written down starting in the twelfth century. ${ }^{13}$

Still, the vast majority of extant written hungry grass sources-folkloric, literary, and journalistic_come after the Famine. As such, it may come as little surprise that the most common explanation - at least during this period, given these sources-is that the hungry grass occurs at locations where a victim of the Famine died, as numerous belief statements in the National Folklore Archives at University College Dublin attest. ${ }^{14} \mathrm{~A}$ brief excerpt from the NFC Main Collection illustrates this belief in a connection between the hungry grass and the Famine, offering both toponymic and physical evidence at a place known as Féar Gortach Brae near Ardara, Co. Donegal:

Tá malaí ar a dtugtar 'an féar gortach' idir seo agus Ard an Rátha agus deirtear go bhfuair fear siúil bás ansin in am an Drochshaoil agus gur cuireadh é san áit ar thit sé. Fá thuairim is 40 bliain ó shin nuair a bhí an bealach mór dá dhéanamh fuarthas cnámha duine curtha san áit.

There is a hill that is called 'the féar gortach' between here and Ardara and it is said that a traveller died there during the Famine and that he was buried where he fell. Around 40 years ago when the road was being built human bones were found buried in the place. (NFC 1068:187-8; also in Póirtéir 1996:123-4)

While this excerpt was sent in response to the Irish Folklore Commission's 1945 Famine questionnaire, similar stories not only circulate at a local level but also get picked up in national media, such as in 1963 when both the Evening Herald and the Irish Independent ran stories about the discovery of human remains at a place locally associated with the hungry grass and Famine burials in Co. Meath (Evening Herald 1963; Irish Independent 1963).

A more contemporary account comes from a 2004 interview by University College Dublin folklore student Rónán Ó Gealbháin. Here, Martina Byrne of Co. Donegal knits together the custom of carrying food on an overland journey to fend against the hungry grass, the Famine explanation of the origin of the hungry grass, and a first-person experience of the phenomenon that culminates in a belief statement:

Nuair a bhí mé i mo chailín óg, bhí mé i mo chonaí i Srathlaofheoil, ait a dtugtar An Cnoc ar. Bhí ceithre tithe ann. Bhí grainín beag caoirí again agus uaireanta chuiagh mé féin agus mo athair amach ar an cnoc chun aire a thabhairt doimh. Bhí rial ag mo athair a bhí an-tabhachtaí ach ní raibh moran ciall agam leis ag an am. Is é an riall na, gan a gabhail amach ar an chnoc gan giota aran, fiú amhain 
crusta no rud in teach eile i do phoca a thiocfadh leat ithe. D'inis sé dom go raibh aiteanna ar an chnoc agus ma théadh trasna orthu thiocfadh gorta millteanach ort agus thiocfadh leat titeadh i laige gan rud ar bith le h-ithe. Deirtear gur iad seo na h-aiteanna a fuair daoine bás i rith an ghorta mór 1847. Tá sé triocha blian ón uair a d'inis se seo dom.

Bhí mé féin agus mo chara Siobhán ag siúl ar an chnoc cúpla mí ó shin, bhí muid ag teacht arais ó Ghleann Loch. Lá deas ghrianmhar a bhí ann ach ar a bhealach arais thainig ocras millteanach orainn. Iontas mór a bhí ann mar tharla sé don bheirt againn go díreach ag an am cheanna. Buíochas le Dia shroich muid an Chaiseal agus fuair muid béile ansin. Thainig scéal mó athair arais dom an lá sin agus creidim é go chinnte go bhfuil a léithid d'aiteanna ann.

When I was a young girl, I was living in Straleel, a place which is called the Hill. There were four houses there. We had a small amount of sheep and sometimes myself and my father went out on the mountain to take care of them. My father had a rule which was very important, but I found little sense in it at the time. The rule was: not to go out on the mountain without a small bit of bread, even a crust or something else, in your pocket that you could eat. He told me that there were places on the mountain that if you were to pass over them you could become extremely hungry and that you could faint without anything to eat. It is said that these are places where people died during the great famine, 1847. It is thirty years since he told me this.

Myself and my friend Siobhán were walking on the mountain a few months ago, we were returning from Glenlough. It was a nice sunny day but on our return, we became extremely hungry. It was a great surprise because it happened to us both at exactly the same time. Thank God, we reached Cashel and we got a meal there. My father's story came back to me that day and I firmly believe that such places exist. (Ó Gealbháin 2004:Appendix A2f)

Folklorist Kevin Danaher summarizes an additional and particularly resonant aspect of this connection to the Famine, observing that the hungry grass "grows on the spot where some poor wretch died of starvation during the Bad Times, and when you step on it you, too, suffer the pangs of famine" (1965:8). In other words, the somatic experience of the hungry grass is widely understood as a kind of re-experiencing. That is, the hungry grass experience is a matter of later unfortunates treading on a place of past tragedy and being made to feel the ravenous hunger and debilitating weakness of a Famine victim just before that person succumbed, at that very spot.

Note that where agency lies-who or what is making people feel hungry-is rather ambiguous. The available records are not clear about whether Famine victim ghosts are the force repeatedly inflicting this starvation experience on those who disturb their places of death. This possibility would be consistent with the traditional belief in Ireland that those who die a bad, untimely death - by murder, suicide, accident, or indeed starvation-will become restless ghosts haunting the places of their demise (also Motifs E275 and E411.10 in Thompson 1960). In addition, this would be conceptually similar to the Hidarugami, "Hungry Souls," of Japanese folklore (Iwasaka and Toelken 1994:89-91; cf. Mizuki 2013:305-12). Alternatively, it could be that the grass growing over the place of a Famine death preserves the imprint of that tragedy, and through some supernatural means-such as contagious magic-the place becomes empowered to subject passersby to the original victim's suffering. 
At such a spot, it is as if the progression of time halts, standing as still as place is immobile, leaving the Famine tragedy to play on a continual loop, absorbing new participants who stray into this unfortunate place-time collision. Any instance of the hungry grass, then, would be referred to as a "chronotope" by Mikhail Bakhtin (1981) or a "placeworld" by Keith Basso (1996) — a spot in the landscape where time, place, and event collapse into a kind of continual happening. Imagining the originary event that generated one such placeworld, Donagh MacDonagh ends his 1947 poem "The Hungry Grass" with a devastating image of a place "grown bewitched," ready to subject otherwise sheltered wanderers of the present to the past experiences of those who have known true horror.

Crossing the shallow holdings high above sea

Where few birds nest, the luckless foot may pass

From the bright safety of experience

Into the terror of the hungry grass.

Here in a year when poison from the air

First withered in despair the growth of spring

Some skull-faced wretch whom nettle could not save

Crept on four bones to his last scattering,

Crept, and the shriveled heart which drove his thought

Towards platters brought in hospitality

Burst as the wizened eyes measured the miles

Like dizzy walls forbidding him the city.

Little the earth reclaimed from that poor body

And yet remembering him the place has grown

Bewitched and the thin grass he nourishes

Racks with his famine, sucks marrow from the bone.

(McDonagh 1947:7)

Of course, there are other folk beliefs about the origin of the hungry grass that do not relate directly to the Famine, but upon examination, the surface differences may mask deeper structural similarities. The second most popular theory in the available materials-and likely the older theory-credits the fairies with either planting the hungry grass or turning grass hungry, as it were, at any spot where people have eaten outdoors but failed to leave a food offering for the fairies or even let crumbs fall in tribute to and reciprocity with them. As mentioned in the beginning, the fairies constitute a kind of alternative society, parallel to our own, and countless fairy legends depict humans being rewarded for doing the fairies a good turn or being punished for crossing them. The idea of the hungry grass being retribution from forsaken, discourteously treated fairies follows the same logic. If the social contract between humans in this world depends on unstinting generosity and generalized reciprocity, so do mutually beneficial, peaceable human-fairy relationships in the world of narrative. Fairy legends, again, offer a removed but relevant realm through which to contemplate proper social norms and values, and the consequences of transgressing them.

Perhaps the fairy explanation and the Famine explanation of the hungry grass coexist because they are not necessarily in competition and may overlap conceptually. 
Indeed, William Carleton virtually knits the two etiologies together in his short story "Fair Gurtha; Or, The Hungry Grass" published in the Dublin University Magazine in the wake of the Famine (1856). ${ }^{15}$ Both the fairy and Famine theories revolve around subjects with whom no food is shared. This failure causes a rupture and perhaps a permanent unluckiness in a world of limited good where open-handedness- "dacency" as Carleton's characters repeatedly refer to it, "decency" as Danny Gallen referred to it when explaining the luck's penny-is required to keep luck in circulation and the bonds of community strong.

Given that reports of the hungry grass pre-date the mid-nineteenth-century Famine, perhaps the Famine explanation is a novel iteration of an older constellation of ideas concerning the connections between fortune, reciprocity, decency, and community. Indeed, as Niall Ó Ciosáin suggests, making the Famine meaningful at all-at the time and in subsequent generations-required creative recycling of previous, already meaningful representations of scarcity and social dissolution (2004). It is possible that the severity of the mid-nineteenth-century Famine would have required the invention of the hungry grass if it had not already existed, if it had not already been available for creative recycling as Famine lore. ${ }^{16}$

Considering the hungry grass in the context of vernacular discourse about the Famine expands our interpretive possibilities by providing a context for how the phenomenon was interpreted in the post-Famine period. Furthermore, given the narrative difficulties of representing the Famine, the belief that the hungry grass was a result of Famine deaths may speak volumes that cannot be expressed fully in a more expository way. Perhaps what resonates most are gestures toward Mac Suibhne's gray zones.

Consider that the post-Famine narrators of hungry grass experiences, such as William McLaughlin quoted earlier, had inherited a decimated world full of largely reticent or, at the very least, unnerved survivors. Reticent why? If I survived but my neighbors did not, could I have done something more for them? Was it the food that I stole for my family - or that I hid or refused to share-what made the difference between life and death for my neighbor in a world of limited good? Perhaps there is room to see something like a collective survivor's guilt at work in post-Famine conceptions of the hungry grass. Such guilt would be collective on the part of the survivors themselves and of their descendants, who would have inherited certain beliefs, customs, and ways of talking directly and indirectly about the undead past, inscribed in the landscape that endures.

The experience of the hungry grass and its narration may pre-date the Famine, but it is notable and telling that the dominant popular etiology after the 1850s connects it to the Famine. It would seem that on some level, for some people, the hungry grass offers itself as a vernacular means to remember and indirectly contemplate the social implications of the Famine for the prospect of community. Thinking of the somatic experience as a matter of feeling what Famine victims felt-but neither oneself nor one's ancestors, who were spared, did-may render the hungry grass a kind of Famine starvation couvade. Here is a phenomenon that may be interpreted as a matter of experiencing vicariously, even empathetically. It is an experience-perhaps like a penance, or at least an uncomfortable acknowledgment-that may help expiate an inchoate, ambient, and perhaps unspeakable sense of guilt among those who survived and their descendants. 
This proposition, whatever its merits, brings to mind a moment a quarter of a century ago when I was taking a history class taught by the late Professor Donnchadh O Corráin at University College Cork. I remember that during class discussion, one of my classmates made a case for how the Irish were uniquely victimized by the Famine and the lack of an adequate response from London. Ó Corráin-perhaps contrarian by nature and certainly not one to be satisfied with a simplistic nationalist spin - pushed back, declaring competitive victimhood exercises unproductive and unenlightening. More pointedly, he gravely intoned, "survivorship means having blood on your hands, and every one of you in this room is the descendant of gombeen men"- a descendant, in other words, of people crafty, mercenary, or simply wealthy enough to have outlived their neighbors.

Back in that moment in the classroom, words came to a halt. If a morsel of oatcake could have dispelled the gut wrench of it all in the silence that ensued, we would have been glad for the relief. But relief was not on offer, and some things become unforgettable even if-or perhaps because-they are difficult to articulate. With such things in mind, today, I have to wonder if the popular interpretation of the hungry grass as haunting Famine echo is a vernacular way-for some people, at certain times-of reiterating Professor Ó Corráin's uncomfortable point.

Whether interpreted in light of the Famine or not, the hungry grass collapses past and present to bear witness to dreadful ruptures in our obligations to each other in this society or, alternatively, between us and those in the parallel society of the fairy Otherworld. In our attempts to understand queer notions and resonant stories that circulate, there may be room to interpret the hungry grass in terms of the return of the repressed (Freud [1900] 1987, 1939), in terms of post-memory (Hirsch 1997, 2012; cf. Beiner 2014), or in terms of any number of contemporary metaphors for grappling with trauma and the undead past. But we are far from the first ones to undertake such grappling. The hungry grass endures not least because, generation after generation, it offers itself for creative recycling in popular thinking about self and society, right and wrong, the ordinary and the extraordinary, this world and the next-a body of vernacular theory otherwise known as folklore.

\section{Conclusion}

Perhaps it is a truism for folklorists that we would do well to pay close attention to beliefs, customs, and stories often uncharitably dismissed as backward, quaint, or trivial. Luck's pennies, witch hares, the hungry grass-these may be notions inherited from the past, but survivals survive for a reason, and many of the ideas they afford and impart have remarkable longevity and daily import (Boas [1927] 1955:7; Evans 1939a, 1939b, 1957; see also Cashman 1996:12-4).

If we seek ethnographic insight into aspects of habitus and worldview-particularly vernacular theorizing about the nature and viability of community-customs such as the luck's penny reveal a long-standing commitment to generalized reciprocity, and a deep-seated ambivalence concerning the anti-communitarian implications of money, profit, and ambition in a world of limited good. Likewise, memorates and legends about witchcraft, the evil eye, and fairy collusion pinpoint further threats to community and suggest how such threats can be diminished or overcome. Narrative 
representations of behaviors that either fail or succeed in advancing community as a social contract for mutual support not only offer exempla for evaluation and possible emulation but also open a window onto shared assumptions about connections between reciprocity, decency, luck, and fortune in a world of limited good.

By extension, in extreme cases when threats to community are insurmountable, we can appreciate how certain forms of folklore cast into relief shared ideas about community through its haunting absence. Legendary materials representing the Famine are indeed fragmentary, indirect, and opaque, but even a Hobbesian nightmare such as the Great Hunger is not untellable (cf. Mac Suibhne 2017b:37). Suggestive beliefs and coded narratives about the hungry grass may evoke uncomfortable social memory and give voice to a collective sense of shame and guilt over the inability to maintain community.

Taken together, the examples from Irish folklore considered here portray community as something other than a static, noun-like entity. Conceptually a social contract for mutual support, community is fundamentally and experientially a doing, a verblike project, potentially under threat at all times, in need of constant maintenance, but nonetheless worth defending.

This older vernacular thinking parallels contemporary academic thinking on a number of related core concepts in folklore studies. Over time, folklorists have shifted focus from a noun-like conception of tradition to the verb-like, agent-driven process of traditionalization (Hymes 1975; Bauman 1992), much as we have shifted from text and context to entextualization and contextualization (Briggs 1988; Bauman and Briggs 1990). In a similar dynamic, vernacular thought, word, and deed should prompt us not only to question simplistic reifications of community but also to appreciate emic perspectives on community as project. Although "community," as a word, does not lend itself to a convenient, accessible neologism with the addition of a verb-signifying suffix such as "-ization" (communitization?), the vernacular concept of community in Ireland, as elsewhere, is clearly understood to be a doing rather than a thing.

If community is a project, it is a never-ending one. We may talk loosely of building community, which gestures appropriately toward the labor involved, but, of course, community is not a building and does not stay built. Not unlike tradition, community requires continual labor and a handing on across generations of the responsibility, knowledge, practices, resources, and overall competence necessary to keep doing the job. ${ }^{17}$ Members of each generation take their turn before eventually handing on the responsibility. While provisional success is possible, some try and fail, and others disassociate from the project entirely, even taking advantage of others' communitarian commitments to reciprocity, for the sake of personal gain. Perhaps it was ever thus, and in some times and places under certain circumstances, the prospect of community would be inconceivable, impossible, were it not for stories, customs, and beliefs that suggest otherwise.

Looking only to the case studies examined here, it should not surprise us that we are not the first to grapple with the nature of community, to struggle with striking balances or coming to terms with failure. Nor should we be surprised to see older ideas, revealed in folklore, informing our thoughts and actions as we negotiate changing times. To be sure, not all the ideas enshrined in our examples are relevant today, some we may find disturbing or retrograde, and indeed any set of ideas taken to an 
extreme is potentially dangerous. But living in an era of rising inequality that largely glorifies negative reciprocity and spares little thought to sustainability or to the general conception of community illustrated here, we may want to explore older models to reconsider the logic of the luck's penny, to interrogate profit and ambition, to look for new ways to exercise older ideals and tested practices.

\section{Acknowledgments}

I would like to thank Dr. Criostóir MacCarthaigh, Director of the National Folklore Collection at University College Dublin, for permission to use NFC materials, and particularly for unstinting generosity with his time and perspectives. My sincere appreciation also goes to Jonny Dillon, Claire Doohan, and Anna Bale at the NFC who have been invariably helpful, hospitable, and patient. I owe Lorraine Walsh Cashman, Michael Dylan Foster, Lisa Gilman, Henry Glassie, and Tom Mould for helping me think through different aspects of community as a cross-cultural phenomenon. Special thanks to Myc Wiatrowski at Indiana University, whose end-of-term research paper put me back in mind of the hungry grass, to Bairbre Ní Fhloinn for alerting me to Rónán Ó Gealbháin's excellent thesis on the topic, to Colm Ó Cuaig and Barbara Hillers for translation assistance, to Marisa Wieneke for exemplary research assistance, and to this journal's two anonymous reviewers who made valuable suggestions for development and improvement. The first full version of this article began as a plenary address to the American Conference for Irish Studies 2018 annual meeting held at University College Cork, where I benefitted from comments and questions from Nessa Cronin, Breandán Mac Suibhne, Stiofan Ó Cadhla, Gearóid Ó Crualaoich, Malcolm Sen, and E. Moore Quinn. I have benefitted from additional comments and questions at subsequent presentations, from Brandon Barker, Maxim Fomin, Éamonn Ó Ciardha, Diarmuid Ó Giolláin, Elliott Oring, Greg Schrempp, Tok Thompson, Peter Smith, and Brittany Warman. Note that parts of the second section, "Community Threatened and Maintained," are recycled, to slightly different ends, from chapter 7 of Packy Jim: Folklore and Worldview on the Irish Border (Cashman 2016).

\section{Notes}

1. A self-reifying process in which community is "built" through a cycle of representation and enactment is illustrated ethnographically in chapter 6 of Tom Mould's Overthrowing the Queen and characterized persuasively as "ostension at its finest" (2020:140). I owe much of my thinking about the cross-cultural similarities and differences in conceptions and performances of community around the world to an organized panel at the 2017 American Folklore Society annual conference that included presentations on Malawi by Lisa Gilman, on Japan by Michael Dylan Foster, on the United States by Tom Mould, and on Ireland by myself. One thing we should not lose sight of in my emphasis here on networks and reciprocity is the "affect of community," as Foster terms it. Exploring his lived experience of participating in a sprawling network of reciprocity on a Japanese island, Foster points out that while the network could be mapped in all its intricacy-and while the exchanges and their economic and social implications could be further analyzed-what struck him most was the sense of being in place, at home, instilled by his participation. I feel certain that this experiential, affecting aspect of community-rather than the transactional subsistence-oriented aspects alone-is a large part of what people miss most or feel most guilty about abandoning when the prospect of community is threatened or becomes impossible, as in the examples from the second half of this article.

2. Although vernacular theorizing takes shape through metaphor and performance rather than through the abstract heuristic models of scholarship, recognizing the analogues between vernacular and academic theorizing is a way of elevating and better appreciating the former while grounding and sharpening the latter. This practice has a long and venerable history in our discipline, Paredes (1958), Glassie (1975), and Noyes (2003a) being but three stellar examples.

3. The Irish Folklore Commission (1935-1971), founded and directed by James Delargy (Séamus Ó Duilearga) and modestly funded by the fledgling Irish Free State, employed full- and part-time collectors to gather and preserve the folklore and folklife of Ireland. Today, the National Folklore Collection 
(NFC), housed at University College Dublin, combines Irish Folklore Commission (IFC) and earlier and later materials in one of the world's most extensive traditional culture archives, recognized in 2017 by the UNESCO Memory of the World Register.

4. See Cashman (2016:196-7, 264-5) for additional context concerning the particular case of Black Henry McCutcheon, and, more generally, for sources and interpretations of the evil eye in Ireland and farther afield.

5. A version of this story is transcribed from a telling on November 18, 2011, in Cashman (2016:1945 ), and the interpretation that follows compares and, to some extent, contrasts with that of Glassie (1982:527-51), Jenkins (1991), and Ní Dhuibhne (1993). A long note on pp. 263-4 of Cashman (2016) offers further context and sources for additional recorded versions of what Christiansen posits as ML (migratory legend type) 3055 (1958:48) and Almqvist posits as MLSIT (migratory legend suggested Irish type) 3056 (1991:268-9)

6. A version of this story is transcribed from a telling on June 18, 2014, in Cashman (2016:197-8).

7. Known in Irish as an Gorta Mór (the Great Hunger) or an Drochshaol (the Bad Times), the usual labels in English - the Irish Potato Famine or just the Famine-engender debate. From the beginning of potato crop failures in 1845 , the island continued to produce every kind of foodstuff except the staple diet of the poor, the potato. When unaffected meat, dairy, seafood, and produce were sold for local consumption or export rather than used to feed the poorest segments of society, we can speak more accurately of a class-specific Starvation rather than a Famine, which implies overall food shortages. Another critique of "the Famine" as a term is that this was not the first or even deadliest potato famine in Ireland - a famine in 1740-1741 is estimated to have killed a higher proportion of the population—nor was it the last. In 1879, a return of the potato blight caused widespread hunger but proportionally fewer deaths due to the sharp decline in the rural landless laborer class from the 1850s, a considerable decrease in land subdivision, crop diversification, and a more meaningful aid response from the government. Having acknowledged that these counterarguments refer to the period between 1845-1852 in Ireland as "the Famine," I will continue to use the term, despite its inaccuracy, because this is the most common and widely recognized label in contemporary usage.

8. See Goldstein and Shuman (2012:119-20) and Goldstein (2012) for discussions of folkloristic interest in tellable and untellable narratives, particularly in contexts of violence and trauma, especially in relation to negotiations over who and what may be considered normal or otherwise may be stigmatized.

9. To take but one of millions of possible examples, in all likelihood, I will never know the full circumstances under which my father's people left Kilvealaton West townland, Glantane parish (a.k.a. Kilshannig), near Mallow, Co. Cork, in 1850. Surviving pre-Famine documentation records their births and marriages; rents and tithes paid (or not); and the location, size, and quality of a rented cottage left behind-variables and details but no exposition. Additional church and civil records gesture slightly further toward narrative by noting the baptism of a child, Johanna, who was born on the eve of the Famine but does not appear in the 1860 US census after these Cashmans emigrated, prompting speculation about how, when, and where the child died. But the details-however plentiful, however black-and-white-are bound to blur in the zones of gray that Mac Suibhne, after Primo Levi (1988), describes (Mac Suibhne 2017b).

10. Generalizations about the hungry grass in the section that follows are drawn from a number of sources. Furthermore, search terms included not only "hungry grass" and "hungry sod" but also multiple and sometime idiosyncratic spellings of the Irish terms "féar gorta" and "fód ghorta" or "fóidín an ocrais" (sod of hunger).

Perhaps the most enlightening sources are those archived in the National Folklore Collection, which includes multiple repositories. The NFC Main Collection (2,400 bound volumes of materials collected mostly in the mid-twentieth century) offers 15 belief statements, memorates, and third-person accounts about the hungry grass, 13 of which are in Irish, having been collected in Irish-speaking areas of the rural west coast (mostly Cos. Clare, Donegal, Galway, Kerry, and Mayo). An additional 32, mostly anglophone texts come from the Schools' Collection (see the next endnote) from counties all over Ireland. Another six sources in English come from the Urban Folklore Project conducted in the Dublin metro area during 1980, and an additional 16 relevant audio interviews were recorded within the last 25 years.

Outside the NFC materials, we find occasional references to the hungry grass, particularly memorates, recorded by contemporary fieldworkers and collectors. For example, in a 1996 article for Folklore Forum, Deborah Davis quotes a woman she met who experienced the hungry grass in Co. Mayo, and Rónán Ó 
Gealbhainn interviewed 10 people with first- or secondhand accounts of the hungry grass in Cos. Clare and Donegal for his 2004 undergraduate thesis in the former Irish Folklore Department at University College Dublin (now the School of Irish, Celtic Studies, and Folklore).

Additional accounts of first- and secondhand experiences with the hungry grass, about half including discussions of the origin of the hungry grass, appear in 71 newspapers articles spanning the twentieth century, in sources with readership ranging from the local and regional (the Strabane Chronicle, the Offaly Independent, the Ulster Herald) to the national (the Irish Independent, the Evening Herald, and the Irish Times).

Nineteenth-century published references to the hungry grass include the short stories and novels of William Carleton $(1844,1847,1856)$ as well as antiquarian writings such as those of Canon John O'Hanlon (a.k.a. Lageniensis, 1870) and William Wilde (1852), father of Oscar Wilde. Finally, the hungry grass is also a frequent allusion in twentieth-century Irish literature such as Donagh MacDonagh's 1947 poetry collection and Richard Power's 1969 novel, both entitled The Hungry Grass. Altogether, these sources speak to the wide circulation of the idea of the hungry grass, at least since the middle of the nineteenth century.

11. One of the Irish Folklore Commission's most successful projects, the Schools' Collection, disseminated surveys to roughly 5,000 primary schools and depended on teachers to organize the materials collected by senior students from their families and neighbors in their home districts. Go to https://www. duchas.ie/en to search the Schools' Collection and additional materials from the National Folklore Collection. This digitization initiative, the Dúchas.ie Project, is a collaboration between the NFC, the National Folklore Foundation, and the Digital Library at University College Dublin; Fiontar \& Scoil na Gaeilge, Dublin City University; and the Department of Culture, Heritage and the Gaeltacht. Note that as more Schools' Collection materials are transcribed by volunteers for duchas.ie, more hungry grass references may come to light, making my total of sources in the previous note something of a moving number.

12. In Irish folklore scholarship, "NFC S" citations refer to the volume followed by page number(s) of materials in the Schools' Collection of the NFC, described in the previous two endnotes. Likewise, "NFC" citations refer to the volume followed by page number(s) of materials in the Main Collection of the NFC.

13. I am grateful to Jonny Dillon of the National Folklore Collection for his observations on special sods in Irish folklore. Camden refers to the sites of accidents where an offending sod must be removed and properly dealt with to avoid fairy enchantment and future misfortune at that spot. Other special sods include those where one is destined to die (fód a bháis, mentioned in the Ulster Cycle as well as in more nearly contemporary lore) and the stray sod (fóidín mearbhaill) where people lose their bearings, a sod that has been enchanted by the fairies or that actuates, for lack of a better term, at the site of a tragic death or unconsecrated burial.

14. Such belief statements tend to be brief answers to the questions of collectors or, more often, codas added to first-person memorates or third-person legendary stories, such as the following: "You would get a 'féar gortach' if you walked on a place where someone died during the famine" (NFC S 80:243) or "A traveller is supposed to take the "Fear Gorta' at the spot where a person or persons died from the famine" (NFC S 978:283).

15. Carleton's short story, written after but set before the Famine, is worth reading for the conceptual connections continually made between the fairies, famine, decency, and reciprocity in a world of limited good. While the hungry grass is explained as the result of not sharing food with the fairies, the common pre-Famine etiology (see Carleton 1840:189), Carleton's short story indulges in wordplay to conjure not just "fair gurtha" (féar gorta) - the hungry grass_but also "far gurtha" (fear gorta) - the hungry man. In short, a wandering starving beggar serves as both the harbinger of the Famine to come and as the vehicle for a test of character. That is, whether or not Carleton's characters share food or money with the hungry man is the ultimate test of their "dacency." Those who do share are told the secret to curing the afflictions of the hungry grass-oaten bread. Those who do not share are subject to poetic justice, such as when the story's most close-fisted offender, Sol, walks over the hungry grass, suffering the usual pains, which in the context of the story delays him and unravels his marriage plans. Likewise, the story's most decent characters, Rose and Mat, are depicted in the story's coda ministering to the poor during the Famine that the hungry man foreshadowed.

16. A relevant concept here is "affordances," brought to my attention by Jennifer Schacker $(2018: 22,56)$. The legend-belief complex of the hungry grass comes with affordances-latent possibilities for expressing 
certain ideas and prompting certain actions relevant to the maintenance of community. Other etiologies may pre-exist the one associated with the Famine, but the hungry grass persists because it affords novel ways of accessing and activating habits of mind that resonate across contexts. The concept of affordances is another way of looking to form and conceptual implication to appreciate that survivals survive for a reason.

17. Compare this to Cashman, Mould, and Shukla (2011:2-4) and Noyes (2009) on the similar dynamic involved in tradition as project.

\section{References Cited}

Almqvist, Bo. 1991. Crossing the Border: A Sampler of Irish Migratory Legends about the Supernatural. Béaloideas 59:210-324.

Arensberg, Conrad. 1937. The Irish Countryman: An Anthropological Study. Gloucester, MA: Peter Smith. Bakhtin, Mikhail M. 1981. The Dialogic Imagination. Trans. Caryl Emerson and Michael Holquist. Austin: University of Texas Press.

Basso, Keith. 1996. Wisdom Sits in Places: Landscape and Language among the Western Apache. Albuquerque: University of New Mexico Press.

Bauman, Richard. 1972a. Differential Identity and the Social Base of Folkore. In Toward New Perspectives in Folklore, ed. Américo Paredes and Richard Bauman, pp. 31-41. Austin: University of Texas Press.

1972b. The La Have Island General Store: Sociability and Verbal Art in a Nova Scotia Community. Journal of American Folklore 85(338):330-43.

- 1992. Contextualization, Tradition, and the Dialogue of Genres: Icelandic Legends of the Kraftaskáld. In Rethinking Context, ed. Alessandro Duranti and Charles Goodwin, pp. 125-45. Cambridge: Cambridge University Press.

Bauman, Richard, and Roger Abrahams, eds. 1981. And Other Neighborly Names: Social Process and Cultural Image in Texas Folklore. Austin: University of Texas Press.

Bauman, Richard, and Charles L. Briggs. 1990. Poetics and Performance as Critical Perspectives on Language and Social Life. Annual Review of Anthropology 19:59-88.

Beiner, Guy. 2014. Probing the Boundaries of Irish Memory: From Prememory to Postmemory and Back. Irish Historical Studies 39(154):296-307.

Bell, Jonathan. 1978. Relations of Mutual Help between Ulster Farmers. Ulster Folklife 24:48-58.

Boas, Franz. [1927] 1955. Primitive Art. New York: Dover.

Bourdieu, Pierre. 1977. Outline of a Theory of Practice. Cambridge: Cambridge University Press.

Bourke, Angela. 1999. The Burning of Bridget Cleary: A True Story. New York: Penguin.

Briggs, Charles. 1988. Competence in Performance: The Creativity of Tradition in Mexicano Verbal Art. Philadelphia: University of Pennsylvania Press.

Camden, William. 1610. Britain, or a Chorographicall Description of the Most Flourishing Kingdomes, England, Scotland, and Ireland, and Ilands Adjoyning, out of the Depth of Antiquitie. Trans. Philemon Holland. London. http://www.philological.bham.ac.uk/cambrit/.

Carleton, William. 1840. Irish Superstitions: Ghosts and Fairies. The Rival Kempers. Irish Penny Journal 1(24):188-91.

- 1844. Phelim O'Toole’s Courtship. In Traits and Stories of the Irish Peasantry. Vol. 2, pp. 188-256. Dublin: William Curry Jr.

- 1847. The Black Prophet: A Tale of Irish Famine. London: Simms and McIntyre.

. 1856. Fair Gurtha; Or, The Hungry Grass. A Legend of the Dumb Hill. Dublin University Magazine 4(280):414-35.

Cashman, Ray. 1996. E. Estyn Evans and His Lasting Importance to the Study of Folklore. Folklore Forum 27(1):3-19.

- 2006. Dying the Good Death: Wake and Funeral Customs in County Tyrone. New Hibernia Review 10(2):9-25.

— 2007. Mumming on the Northern Irish Border: Social and Political Implications. In BorderCrossing: Mumming in Cross-Border and Cross-Community Contexts, ed. Anthony Buckley, Críostóir Mac Cárthaigh, Séamas Mac Mathúna, and Séamas Ó Catháin, pp. 39-56. Dundalk: Dundalgan Press. 
2008a. Storytelling and the Construction of Local Identities on the Irish Border. In Anáil an Bhéil Bheo: Orality and Modern Irish Culture, ed. Nessa Cronin, Seán Crosson, and John Eastlake, pp. 115-25. Newcastle upon Tyne: Cambridge Scholars.

2008b. Storytelling on the Northern Irish Border: Characters and Community. Bloomington: Indiana University Press.

- 2016. Packy Jim: Folklore and Worldview on the Irish Border. Madison: University of Wisconsin Press.

Cashman, Ray, Tom Mould, and Pravina Shukla. 2011. The Individual and Tradition: Folkloristic Perspectives. Bloomington: Indiana University Press.

Christiansen, Reidar Thoralf. 1958. The Migratory Legends: A Proposed List with a Systematic Catalogue of the Norwegian Variants. FF Communications No. 175. Helsinki: Suomalainen Tiedeakatemia.

DaMatta, Roberto. 1992. Carnivals, Rogues, and Heroes: An Interpretation of the Brazilian Dilemma. South Bend, IN: University of Notre Dame Press.

Danaher, Kevin. 1965. The Hungry Grass. Offaly Independent, June 12:8.

Davis, Deborah R. 1996. Famine Ghosts and the Féar Gortach: A Strand of Irish Belief. Folklore Forum 27(2):39-52.

Evans, E. Estyn. 1939a. Donegal Survivals. Antiquity: A Quarterly Review of Archaeology 13:207-22.

1939b. Some Survivals of the Irish Openfield System. Geography: The Quarterly Journal of the Geographical Association 24:24-36.

- 1957. Irish Folk Ways. New York: Routledge.

Evening Herald. 1963. Remains Found in Co. Meath. March 19:5.

Foster, George. 1965. Peasant Society and the Image of Limited Good. American Anthropologist 67(2):293315.

Freud, Sigmund. [1900] 1987. The Interpretation of Dreams. New York: Chelsea House.

-1939. Moses and Monotheism. New York: Knopf.

Glassie, Henry. 1975. All Silver and No Brass: An Irish Christmas Mumming. Bloomington: Indiana University Press.

- 1982. Passing the Time in Ballymenone: History and Culture of an Ulster Community. Philadelphia: University of Pennsylvania Press.

. 2006. The Stars of Ballymenone. Bloomington: Indiana University Press.

Goldstein, Diane. 2012. Rethinking Ventriloquism: Untellability, Chaotic Narratives, Social Justice, and the Choice to Speak For, About, and Without. Journal of Folklore Research 49(2):179-98.

Goldstein, Diane, and Amy Shuman. 2012. The Stigmatized Vernacular: Where Reflexity Meets Untellability. Journal of Folklore Research 49(2):113-26.

Graeber, David. 2001. Toward an Anthropological Theory of Value: The False Coin of Our Own Dreams. New York: Palgrave.

Hirsch, Marianne. 1997. Family Frames: Photography, Narrative, and Postmemory. Cambridge, MA: Harvard University Press.

- 2012. The Generation of Postmemory: Writing and Visual Culture after the Holocaust. New York: Columbia University Press.

Hymes, Dell. 1975. Folklore's Nature and the Sun's Myth. Journal of American Folklore 88(359):345-69.

Irish Independent. 1963. Meath Find of Human Skeletons. March 20:16.

Iwasaka, Michiko, and Barre Toelken. 1994. Ghosts and the Japanese: Cultural Experience in Japanese Death Legends. Logan: Utah State University Press.

Jackson, Jason Baird. 2013. The Story of Colonialism, or Rethinking the Ox-Hide Purchase in Native North America and Beyond. Journal of American Folklore 126(499):31-54.

Jenkins, Richard. 1991. Witches and Fairies: Supernatural Aggression and Deviance among the Irish Peasantry. In The Good People: New Fairylore Essays, ed. Peter Narváez, pp. 302-35. New York: Garland.

Lauper, Cyndi. 1983. Money Changes Everything. She's So Unusual. Portrait Records, FR 38930. Audio recording.

Levi, Primo. 1988. The Drowned and the Saved. Trans. Raymond Rosenthal. New York: Vintage International. Mac Suibhne, Breandán. 2017a. The End of Outrage: Post-Famine Adjustment in Rural Ireland. Oxford: Oxford University Press. 
2017b. Subjects Lacking Words? The Gray Zone of the Great Famine. Cork: Cork University Press. Mauss, Marcel. [1950] 1990. The Gift: The Form and Reason for Exchange in Archaic Societies. London: Routledge Classics.

McCabe, Conor. 2018. Money. Cork: Cork University Press.

McDonagh, Donagh. 1947. The Hungry Grass. London: Faber \& Faber.

McDowell, John. 2008. Poetry and Violence: The Ballad Tradition of Mexico's Costa Chica. Urbana: University of Illinois Press.

Mizuki, Shigeru. 2013. Showa: A History of Japan 1926-1939. Trans. Zack Davisson. New York: Drawn and Quarterly.

Mould, Tom. 2020. Overthrowing the Queen: Telling Stories of Welfare in America. Bloomington: Indiana University Press.

Ní Dhuibhne, Éilís. 1993. The Old Woman as Hare: Structure and Meaning in an Irish Legend. Folklore 104(1-2):77-85.

Noyes, Dorothy. 2003a. Fire in the Placa: Catalan Festival Politics after Franco. Philadelphia: University of Pennsylvania Press.

- 2003b. Group. In Eight Words for the Study of Expressive Culture, ed. Burt Feintuch, pp. 7-41. Urbana: University of Illinois Press.

- 2009. Tradition: Three Traditions. Journal of Folklore Research 46(3):233-68.

- 2012. The Social Base of Folklore. In A Companion to Folklore, ed. Regina Bendix and Galit Hasan-Rokem, pp. 13-39. Hoboken, NJ: Blackwell.

- 2016. Humble Theory: Folklore's Grasp on Social Life. Bloomington: Indiana University Press.

Ó Ciosáin, Niall. 1995. Was There 'Silence' about the Famine? Irish Studies Review 4(13):7-10.

- 2001. Famine Memory and the Popular Representation of Scarcity. In History and Memory in Modern Ireland, ed. Ian McBride, pp. 95-117. Cambridge: Cambridge University Press.

- 2004. Approaching a Folklore Archive: The Irish Folklore Commission and the Memory of the Great Famine. Folklore 115:222-32.

Ó Gealbháin, Rónán. 2004. An Féar Gortach. Unpublished undergraduate thesis, University College Dublin.

O’Grada, Cormac. 1994. An Drochshaol: Béaloideas agus Amhráin. Dublin: Coiscéim.

- 2001. Famine, Trauma and Memory. Béaloideas 69:121-43.

O'Hanlon, Canon John (a.k.a. Lageniensis). 1870. Irish Folk Lore: Traditions and Superstitions of the Country, with Humorous Tales. Glasgow: Cameron \& Ferguson.

Paredes, Américo. 1958. With His Pistol in His Hand: A Border Ballad and Its Hero. Austin: University of Texas Press.

Póirtéir, Cathal. 1995a. Famine Echoes: Folk Memories of the Great Irish Famine. Dublin: Gill and Macmillan.

- 1995b. Gnéithe den Ghorta. Dublin: Coiscéim.

-1996. Glórtha ón Ghorta: Béaloideas na Gaeilge agus an Gorta Mór. Dublin: Coiscéim.

Power, Richard. 1969. The Hungry Grass. New York: Dial Press.

Rieti, Barbara. 2008. Making Witches: Newfoundland Traditions of Spells and Counterspells. Montreal, QC: McGill-Queen's University Press.

Sahlins, Marshall. 1972. Stone Age Economics. Chicago: Aldine-Atherton.

Schacker, Jennifer. 2018. Staging Fairyland: Folklore, Children's Entertainment, and Nineteenth-Century Pantomime. Detroit, MI: Wayne State University Press.

Thompson, Stith. 1960. Motif-Index of Folk-Literature: A Classification of Narrative Elements in Folktales, Ballads, Myths, Fables, Mediaeval Romances, Exempla, Fabliaux, Jest-Books, and Local Legends. 6 vols. (Rev. edition). Bloomington: Indiana University Press.

Wilde, William Robert. 1852. Irish Popular Superstitions. Dublin: James McGlashan. 